\title{
Oral hygiene, dietary habits and prevalence of dental caries in ado- lescents from rural and urban areas in Rio Grande do Sul, Brazil
}

\author{
Higiene bucal, hábitos alimentares e prevalência de cárie dentária em adolescentes da \\ zona rural e urbana no Rio Grande do Sul, Brasil
}

\author{
Tássia Silvana BORGES ${ }^{1}$ \\ Moisés Zacarias CARDOSO ${ }^{1}$ \\ Mixianni Justo FORTUNA ${ }^{1}$ \\ Cézane Priscila REUTER ${ }^{2}$ \\ Simone IMPERATORE ${ }^{3}$ \\ Silvia Isabel Rech FRANKE ${ }^{4}$ \\ Miria Suzana BURGOS²
}

\section{ABSTRACT}

\section{Objective}

To determine the condition of oral hygiene, dietary habits and prevalence of dental caries in adolescents, listing these habits and comparing residents from rural and urban areas.

\section{Methods}

Cross-sectional study involving of 623 adolescents of both sexes, aged 12 to 17 year old in Santa Cruz do Sul, Brazil. Data were collected through sociodemographic questionnaires and dental examination. We conducted a descriptive analysis of the exposure variables and outcome. A bivariate analysis was then performed using the Chi-square test.

\section{Results}

The prevalence of caries was $63.6 \%$, in which adolescents living in rural areas had a prevalence of $70.7 \%$ and $56.4 \%$ in the urban area. The level of mother's education $\leq 4$ years and socioeconomic class B1/B2 and C1/C2 showed statistically significant differences between the areas of residence. Among the demographic variables, the rural area showed a higher prevalence of caries.

\section{Conclusion}

The results showed a high prevalence of dental caries among the adolescents studied and indicate a correlation between prevalence and the low level of mother's education, socioeconomic status (low to medium) and residence in rural areas. It should be understood that, while the multifactorial nature and stratified caries actions are not taken into consideration, the actions implemented will continue to fail, frustrating the expectations set by government entities.

Indexing terms: Adolescents. Dental caries. Epidemiology.

\section{RESUMO}

\section{Objetivo}

Verificar a condição de higiene bucal, hábitos alimentares e prevalência de cárie dentária em adolescentes, relacionando tais hábitos e comparando residentes da zona rural e urbana.

\section{Métodos}

Estudo transversal, composto por 623 adolescentes de ambos os sexos, com idade entre 12 e 17 anos do município de Santa Cruz do Sul, Rio Grande do Sul, Brasil. Os dados foram coletados através de questionários sociodemográficos e exame clínico odontológico. Realizou-se análise descritiva das variáveis de exposição e desfecho. A análise bivariada foi realizada através de teste de qui-quadrado.

\section{Resultados}

A prevalência de cárie foi de $63,6 \%$, na qual os adolescentes da zona rural apresentaram prevalência de $70,7 \%$ e os da zona urbana $56,4 \%$. O grau de instrução materna $\leq 4$ anos e a classe socioeconômica B1/B2 e C1/C2 apresentaram diferenças estatisticamente significativas entre as zonas de moradia. Entre as variáveis demográficas, a zona rural apresentou maior prevalência de cárie.

\section{Conclusão}

Os resultados evidenciaram alta prevalência de cárie entre os adolescentes e indicam uma correlação da prevalência com a baixa escolaridade materna, classe socioeconômica (média a baixa) e a residência na zona rural. Deve-se compreender que, enquanto não for levado em consideração a multifatoriedade e a ação estratificada da doença cárie, as ações implementadas continuarão falhando e frustrando as expectativas estabelecidas pelas entidades governamentais.

Termos de indexação: Adolescente. Cárie dentária. Epidemiologia.

\footnotetext{
${ }^{1}$ Universidade Luterana do Brasil, Programa de Pós-Graduação em Odontologia, Departamento de Odontopediatria. Canoas, RS, Brasil.

2 Universidade Federal do Rio Grande do Sul, Programa de Pós-Graduação em Saúde da Criança e do Adolescente, Departamento de Educação Física e Saúde. Av. Independência, 2293, Universitário, bloco 42, sala 4206, 96815-060, Santa Cruz do Sul, RS, Brasil. Correspondência para / Correspondence to: MS BURGOS. E-mail: <mburgos@unisc.br>.

3 Universidade Luterana do Brasil, Departamento de Odontologia. Canoas, RS, Brasil.

${ }^{4}$ Universidade de Santa Cruz do Sul, Programa de Pós-Graduação em Promoção da Saúde, Departamento de Nutrição. Santa Cruz do Sul, RS, Brasil.
} 


\section{INTRODUCTION}

Oral health is a complex concept that cannot be simply boiled down to the health of the teeth'. Oral diseases result in limitations on routine daily activities, causing impacts of a psychological, physical or social nature, with a significant reduction in the quality of life ${ }^{2}$. Given these implications and with a view to expanding the insertion of oral health into the scope of Brazil's National Health System (SUS), a National Oral Health Policy, known as Brasil Sorridente (Smiling Brazil), was launched, and which is still in effect today ${ }^{3}$.

The premise of this national policy is to qualify primary healthcare, work with health surveillance, plan actions in conjunction with the epidemiology and local information from the territories, as well as to fund research based on scientific evidence ${ }^{3}$. We stress that, given these objectives, a national survey is being enhanced, seeking to identify the oral health situation of the Brazilian population. The most recent edition of the epidemiological survey SB Brasil (Oral Health Brazil) took place in 2010. The results of this survey included 37,519 individuals across a variety of age ranges in the 26 state capitals, the Federal District of Brasilia and a further 150 municipalities in the hinterlands ${ }^{4}$. However, only the urban areas of municipalities were researched and only oral health condition and access to health services were surveyed, with no data collected on dietary or hygiene habits.

Questions regarding dietary habit and oral health are colected, taking into account that an unregulated diet may be harmful when lacking nutrients or when excessive, and could delay physiological and dental development, increasing the occurrence of carious lesions in both the deciduous and permanent dentitions ${ }^{5-6}$.

As for oral hygiene habits, some studies have shown that increased frequency of brushing resulted in a reduction of the prevalence of caries 5,7 , with parental supervision and school programs on oral hygiene education during infancy, are regarded as essential for obtaining such results ${ }^{7-8}$.

Another factor that should be emphasized is the area where the schoolchildren live. Some studies have shown that residents of rural areas have a greater prevalence and seriousness of caries disease, when compared with those living in urban areas ${ }^{9-10}$. The literature stresses that the main causes for this difference lie in the existence of worse income indicators in the rural areas in Brazil, the precarious conditions of basic sanitation and low levels of schooling, which represent a significant concentration of risks to oral health in this population ${ }^{11}$. In addition to these reasons, the difficulty of access to dental services, lack of oral hygiene instruction and, in some cases, the absence of fluoride in the water supply in the rural areas, may be mentioned ${ }^{10,12-15}$. These differences must be taken into account, mainly when planning public oral health policy.

Given the premise and the current oral health policy, this study investigated oral hygiene, dietary habits and the prevalence of dental caries in adolescents in the city of Santa Cruz do Sul and comparing residents from rural and urban areas.

\section{METHODS}

\section{Study subjects and design}

A cross-sectional study was carried out in a sample of 623 male and female adolescents aged between 12 and 17, attending public and private schools in the city of Santa Cruz do Sul, Rio Grande do Sul, Brazil.

Santa Cruz do Sul has a population of 118,374 , according to the census conducted by the Brazilian Institute of Geography and Statistics (IBGE) ${ }^{16}$. The composition of the population is as follows: 105,190 inhabitants in urban areas and 13,184 rural inhabitants. The Human Development Index (HDI) is 0.773 . The city currently boasts $99 \%$ of households served by drinking water with adequate fluoridation.

The National Health Service (SUS) comprises 64 establishments, of which 12 are Basic Health Units (UBS) (4 in rural and 8 in urban areas) and six have a Dental Surgeon. It has 10 Family Health Strategies (ESF) (1 in the rural area and 9 in urban areas), of which four have an oral health team ${ }^{17}$

The reference population for the study consisted of around 20,540 pupils from public and private elementary and high schools in the city of Santa Cruz do Sul, stratified into rural and urban areas and, in addition, by center or suburbs: North, South, East or West. In total, the city has 69 schools of which eight are private, all of which are located in the urban area, 30 are state schools and 31 are municipal. In the rural area there are 6 state schools and 16 municipal schools; the rest are located in urban areas ${ }^{17}$.

The sample size was calculated with the version 7 of the Epi-Info software program (Centers for Disease Control and Prevention, Atlanta, GA, USA) was used. The 
prevalence of dental caries used for the calculation was $56 \%{ }^{4}$, with a power of $80 \%$ and standard error of $5 \%$. Based on these parameters, the minimum sample size was 362 . When the confusion variables were added in to control the effect at $20 \%$ and adding a further $20 \%$ for losses and refusals, the resulting sample size required was 522.

\section{Study variables}

For the oral health-related evaluation of the schoolchildren, examiner calibration was carried out in which the Kappa test showed agreement of $K=0.90$. The oral health evaluation was conducted in the University Research Laboratory by a previously trained researcher using the SB Brasil (2010) project protocol ${ }^{4}$. During the oral examination, the student and researcher remained seated on ordinary school chairs, next to a window so that the maximum amount of natural light was obtained. The average duration of the dental examination was 10 minutes. The examination was performed using a WHO type periodontal probe (ballpoint) and a no. 5 flat surface oral mirror for epidemiological surveys ${ }^{18}$; all were packed in surgical, autoclave paper. No form of radiography was conducted, stressing the fact that there was no prior brushing or prophylaxis of the teeth prior to the examination. All codes and criteria were noted on separate sheets for each student. The DMFT index was used (decayed, missing, filled/restored teeth) for the permanent dentition, as per WHO criteria.

Socioeconomic conditions as well as the level of mother's schooling were evaluated using an adapted questionnaire, in accordance with the criteria of the Brazilian Association of Market Research Companies $(A B E P)^{19}$. The level of mother's schooling was discretely obtained and subsequently classified into three categories: less than or equal to 4 years of study; between 5 and 11 years and greater than 12 years of study.

The body mass index (BMI) was evaluated via the ratio of total body mass (weight $(\mathrm{kg})$ divided by height $(\mathrm{m})$ squared) and subsequently classified, using the protocol of Conde \& Monteiro20, by sex and age, with low weight being considered as $<\mathrm{p} 3$, normal weight $\geq \mathrm{p} 3$ and $<\mathrm{p} 85$, overweight $\mathrm{p} \geq 85$ and $<\mathrm{p} 97$, and obesity $\geq$ p97. This anthropometric evaluation was carried out by a single, suitably trained and qualified Physical Education professional.

Eating and drinking habits (consumption of soft drinks and fruit) were collected at various times during the week and subsequently categorized as high or low consumption, in accordance with the literature ${ }^{21-22}$. The behavioral variables were collected through the literature, adapted from Barros \& Nahas ${ }^{23}$.

\section{Ethical aspects}

The research project was approved by the Research Ethics Committee at the University of Santa Cruz do Sul, under document no. 3044/11, in compliance with the Declaration of Helsinki. A free and informed consent form was signed by the parents or guardians of all the participating schoolchildren.

\section{Statistical analysis}

Data analysis was carried out using the SPSS 20.0 for Windows application (IBM Corp. Released 2011, Armonk, NY: IBM Corp. USA). Firstly, a descriptive analysis of the exposure and outcome variables was conducted, with absolute values and relative percentages. The bivariate analysis was carried out using the chi-square and linear trend chi-square tests.

\section{RESULTS}

A total of 623 adolescents aged 12-to 17 year old were examined in Santa Cruz do Sul, Rio Grande do Sul, Brazil. In both urban and rural areas, the female sex was more prevalent, as was the state school. The level of mother's schooling was $\leq 4$ years and the socioeconomic classes B1/B2 and C1/C2 presented statistically significant differences between the residential areas. The majority of schoolchildren had normal BMI and the most reported frequency of brushing was 1 to 3 times a day, there being no significant differences between the city's rural and urban areas (Table 1). 
Table 1. Descriptive characteristics of the sample, $n=623$. Santa Cruz do Sul, 2012/2013.

\begin{tabular}{|c|c|c|c|}
\hline Variable & $\begin{array}{c}\text { Urban Zone } \\
n(\%)\end{array}$ & $\begin{array}{c}\text { Rural Zone } \\
n(\%)\end{array}$ & $p$ \\
\hline Sex & & & $0.003^{*}$ \\
\hline Male & $114(36.5)$ & $148(47.6)$ & \\
\hline Female & $198(63.5)$ & $163(52.4)$ & \\
\hline Type of School & & & $0.000 *$ \\
\hline State & $244(78.2)$ & $163(52.4)$ & \\
\hline Municipal & $46(14.7)$ & $148(47.6)$ & \\
\hline Private & $22(7.1)$ & - & \\
\hline Mother's level of education & & & $0.000 * *$ \\
\hline$\leq 4$ years & $128(41.0)$ & $241(77.5)$ & \\
\hline $5-11$ years & $141(45.2)$ & $56(18.0)$ & \\
\hline$\geq 12$ years & $43(13.8)$ & $14(4.5)$ & \\
\hline ABEP Criteria & & & $0.000 * *$ \\
\hline Class A1/A2 & $20(6.4)$ & $01(0.3)$ & \\
\hline Class B1/B2 & $166(53.2)$ & $128(41.3)$ & \\
\hline Class $\mathrm{C} 1 / \mathrm{C} 2$ & $118(37.8)$ & $168(54.2)$ & \\
\hline Class D/E & $8(2.6)$ & $13(4.2)$ & \\
\hline BMI Classification & & & $0.292 *$ \\
\hline Underweight & $5(1.6)$ & $7(2.3)$ & \\
\hline Normal & $231(74.0)$ & $225(72.3)$ & \\
\hline Overweight & $53(17.0)$ & $44(14.1)$ & \\
\hline Obesity & $23(7.4)$ & $35(11.3)$ & \\
\hline Frequency of Brushing & & & $0.729 * *$ \\
\hline 1 to 3 times a day & $256(82.1)$ & $262(84.2)$ & \\
\hline 4 to 5 times a day & $47(15.1)$ & $40(12.9)$ & \\
\hline 1 to 3 times a week & $9(2.9)$ & $9(2.9)$ & \\
\hline Use of Dental Floss & & & $0.003 * *$ \\
\hline Yes, daily & $65(20.8)$ & $89(28.6)$ & \\
\hline Sometimes & $158(50.6)$ & $166(53.4)$ & \\
\hline Never, rarely & $89(28.5)$ & $56(18.0)$ & \\
\hline
\end{tabular}

Chi-square Test *; Chi-square test for linear trends **

Table 2 shoes the results for DMFT $\geq 1$ between the city zones and the schoolchildren's dietary habits. The results demonstrate that only the consumption of savory snacks was significant in the urban area, exhibiting the highest percentage of consumption of 2 to 6 times a week.

Table 2. Prevalence of dental caries (DMFT) and relationship to dietary habits in adolescents residing in the urban and rural areas of Santa Cruz do Sul, (RS) $2012 / 2013$.

\begin{tabular}{|c|c|c|c|c|}
\hline Variable & $\begin{array}{c}\text { Urban Zone } \\
\text { DMFT } \geq 1 \\
n(\%)\end{array}$ & $\mathrm{p}$ & $\begin{array}{c}\text { Rural Zone } \\
\text { DMFT } \geq 1 \\
n(\%)\end{array}$ & $\mathrm{p}$ \\
\hline Classification of confectionery & & 0.408 & & 0.298 \\
\hline None & $9(5.1)$ & & $10(4.5)$ & \\
\hline Once a week & $48(27.3)$ & & $83(37.7)$ & \\
\hline 2 to 6 times a week & $82(46.6)$ & & $69(31.4)$ & \\
\hline 1 to 3 or more times a day & $37(21.0)$ & & $58(26.4)$ & \\
\hline Classification of savory snacks & & $0.017^{*}$ & & 0.342 \\
\hline None & $13(7.4)$ & & $16(7.3)$ & \\
\hline Once a week & $60(34.1)$ & & $104(47.3)$ & \\
\hline 2 to 6 times a week & $76(43.2)$ & & $68(30.9)$ & \\
\hline 1 to 3 or more times a day & $27(15.3)$ & & $32(14.5)$ & \\
\hline Classification of soft drinks & & 0.264 & & 0.695 \\
\hline None & $6(3.4)$ & & $6(2.7)$ & \\
\hline Once a week & $47(26.7)$ & & $81(36.8)$ & \\
\hline 2 to 6 times a week & $80(45.5)$ & & $87(39.5)$ & \\
\hline 1 to 3 or more times a day & $43(24.4)$ & & $46(20.9)$ & \\
\hline Classification of Fruit Juices & & 0.624 & & 0.820 \\
\hline None/ once a week & $79(44.9)$ & & $95(43.2)$ & \\
\hline 2 to 6 times a week & 65 (36.9) & & $83(37.7)$ & \\
\hline 1 to 3 or more times a day & $32(18.2)$ & & $42(19.1)$ & \\
\hline
\end{tabular}

Chi-square test * 
Table 3 displays the results divided into DMFT $=0$ and DMFT $\geq 1$ comparing the demographic, socioeconomic and nutritional variables. Among the demographic variables, there was a significant difference between residential zones, with the rural area having the higher prevalence of caries. All the socioeconomic variables showed significant differences when comparing DMFT, however, among the nutritional variables, only the consumption of savory snacks continued to be associated.

Table 3. Prevalence of caries according to study variables. Santa Cruz do Sul, (RS) 2012/2013.

\begin{tabular}{|c|c|c|c|}
\hline Variables & $\begin{array}{c}\text { DMFT }=0 \\
n(\%)\end{array}$ & $\begin{array}{c}\text { DMFT } \geq 1 \\
n(\%)\end{array}$ & $\mathrm{p}$ \\
\hline \multicolumn{4}{|l|}{ Demographic variables } \\
\hline Sex & & & $0.204^{*}$ \\
\hline Male & $103(45.4)$ & $159(40.2)$ & \\
\hline Female & $124(54.6)$ & $237(59.8)$ & \\
\hline Residential zone & & & $<0.001 *$ \\
\hline Rural & $91(40.1)$ & $220(55.6)$ & \\
\hline Urban & $136(59.9)$ & $176(44.4)$ & \\
\hline \multicolumn{4}{|l|}{ Socioeconomic variables } \\
\hline \multicolumn{4}{|l|}{ Type of School } \\
\hline State & $148(65.2)$ & $259(65.4)$ & $<0.001$ * \\
\hline Municipal & $60(26.4)$ & $134(33.8)$ & \\
\hline Private & $19(8.4)$ & $3(0.8)$ & \\
\hline Mother's level of education & & & $<0.001 * *$ \\
\hline$\leq 4$ years & $111(48.9)$ & $258(65.2)$ & \\
\hline 5-11 years & $78(34.4)$ & $119(30.1)$ & \\
\hline$\geq 12$ years & $38(16.7)$ & $19(4.8)$ & \\
\hline Family income (ABEP Criteria) & & & $0.018 * *$ \\
\hline Class $\mathrm{A} 1$ and $\mathrm{A} 2$ & $14(6.2)$ & $7(1.8)$ & \\
\hline Class B1 and B2 & $113(50.0)$ & $181(45.7)$ & \\
\hline Class $C 1$ and $C 2$ & $90(39.8)$ & $196(49.5)$ & \\
\hline Class $\mathrm{D}$ and $\mathrm{E}$ & $9(4.0)$ & $12(3.0)$ & \\
\hline \multicolumn{4}{|l|}{ Nutritional variables } \\
\hline BMI & & & $0.569 * *$ \\
\hline Normal & $169(74.4)$ & $299(75.5)$ & \\
\hline Overweight & $34(15.0)$ & $63(15.9)$ & \\
\hline Obese & $24(10.6)$ & $34(8.6)$ & \\
\hline Consumption of Soft Drinks & & & $0.371 * *$ \\
\hline None & $10(4.4)$ & $12(3.0)$ & \\
\hline Once a week & $83(36.6)$ & $128(32.3)$ & \\
\hline 2 to 6 times a week & $81(35.7)$ & $167(42.2)$ & \\
\hline 1 to 3 or more times a day & $53(23.3)$ & $89(22.8)$ & \\
\hline Consumption of Savory Snacks & & & $0.025 * *$ \\
\hline None & $26(11.5)$ & $29(7.3)$ & \\
\hline Once a week & $106(46.7)$ & $164(41.4)$ & \\
\hline 2 to 6 times a week & $66(29.1)$ & $144(36.4)$ & \\
\hline 1 to 3 or more times a day & $29(12.8)$ & $59(14.9)$ & \\
\hline Consumption of Confectionery & & & $0.224 * *$ \\
\hline None & $13(5.7)$ & $19(4.8)$ & \\
\hline Once a week & $82(36.1)$ & $131(33.1)$ & \\
\hline 2 to 6 times a week & $86(37.9)$ & $151(38.1)$ & \\
\hline 1 to 3 or more times a day & $46(20.3)$ & $95(24.0)$ & \\
\hline
\end{tabular}

Chi-square Test *; Chi-square test for linear trends **

The prevalence of caries in the sample was $63.6 \%$, with the adolescents residing in the rural area having a prevalence of $70.7 \%$ and those in the urban zone, $56.4 \%$ (Figure 1). 


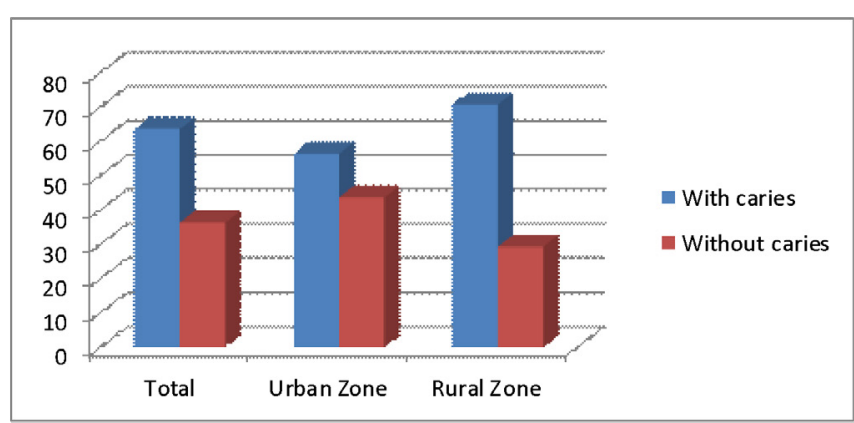

Figure 1. Percentage of adolescents with caries and overall without caries in the urban and rural zones of Santa Cruz do Sul (RS), 2012/2013.

\section{DISCUSSION}

Despite the dental caries is a much-studied oral disease, the majority of studies have focused on children of pre-school age, there being insufficient data in the literature about coverage in adolescents ${ }^{24}$. This study investigated the prevalence of dental caries related to the diet of adolescents aged 12-17 year old, so that the oral condition of this age group could be characterized and the residential conditions (urban or rural) ascertained.

The prevalence of caries in this study was relatively high $(63.6 \%)$, the outcome being similar to studies involving adolescents in different regions of the country, ranging from $61 \%$ to $74 \%{ }^{25-27}$, demonstrating that caries is still a public health issue, and that its prevalence is high even before the permanent dentition is complete. There is, therefore, a need for greater investment in the prevention of carious lesions, in order to prevent curative and invasive treatment that is more expensive, requiring a better infrastructure to carry out said treatment.

With regard to the residential zone, it can be seen that those individuals living in rural areas had a higher prevalence of caries and that there was a statistical difference, in line with national and international studies ${ }^{5,9,10,28-29}$. This fact may be related to the difficult access to health services for people living in rural areas, as well as the fact that most of them belong to less advantaged social classes, or even the lack of fluoride in the water supply,9-10. Some national and international studies have shown that although the prevalence of caries is still high, the severity of the disease has diminished and this phenomenon is true for both rural and urban zones, with a greater intensity in the latter, and this is due to the better access to information and oral health services ${ }^{10,29}$. However, the form of coverage and the preventive focus still need improvement, mainly when related to residents of the rural areas, for these indices to improve even more.

If we look at the four national epidemiological surveys (1986, 1996, 2003 and 2010)4,30-32, it can be seen that none of them stratifies in the results the caries index by residential zone, which could adversely affect the implementation of oral health policies since, as our study and other surveys have shown, there is a significant difference ${ }^{9,30-33}$. Accordingly, to get better coverage of preventive and curative measures, there is a need to understand the reality of each population, their peculiarities, their hardships, and the factors that make them more or less susceptible to the health outcome. If this concern were evident prior to the implementation of health programs, the results would be more consistent with positive indicators.

Despite the small number of students from private schools, it can be observed from this survey that students in public schools had a far higher prevalence of caries than students in private schools, and these findings were statistically significant and consistent with results found in studies in different regions ${ }^{11,27,34}$. According to the literature, we might suggest that our results are a consequence of the better quality of life of schoolchildren in the private system, with access to health, education and treated water, and to the absence of oral health policies directed towards users of the public education system.

As for the mother's level of schooling and family income, we can state that both these factors are seen to be heavily linked to dental caries, in both urban and rural areas, reinforcing the findings of Gomes et al. ${ }^{35}$; Ferreira et al. ${ }^{36}$; Kramer et al. ${ }^{37}$ and partially in agreement with Zardetto ${ }^{26}$, who found no statistical difference in terms of family income. These results reinforce the influence of the level of mother's schooling and family income on the outcomes related to oral and overall health, as both of these factors are heavily associated with the presence of risks to health, including dental caries. Both variables should be considered in the planning of curative and preventive measures, by prioritizing the education of mothers with lower levels of schooling and disadvantaged families, in order to obtain a reduction in the indices of caries and the severity of the disease (polarization groups).

Regarding oral hygiene, it can be seen that there was no statistical difference between the frequency of 
brushing and the residential zone. This result is similar to that of Levine et al. ${ }^{5}$, who showed there was no difference between the child's geographical location and the frequency of brushing, however, there was a difference in the prevalence of caries in people living in the rural zone who did not brush their teeth on a daily basis (relatively higher), probably caused by the lower access to dental services and the absence of fluoride in the water supply. These findings show that access to brushing already encompasses the rural and urban areas in equal proportions, however, very close attention should be paid to those living in rural areas who do not practice regular oral hygiene, as these people will be more susceptible to carious lesions.

Diet, especially one rich in sugary foods, assumes an important role in the occurrence of dental caries, as it provides the main cariogenic substrate, has an influence on the production of acids, changes the type and quantity of dental biofilm, and also interferes with the composition of microorganisms and the quality and quantity of saliva production ${ }^{38}$. The consumption of cariogenic products, especially where intake is frequent, seems to be the most widely accepted behavioral factor in the development of the caries process ${ }^{39}$. This study showed that the consumption of processed products may be responsible for the experience of caries in adolescents in the city, particularly when the frequency of consumption of these items is taken into account, as individuals who ingest these foods may have a greater prevalence of caries than those who do not and the increase in weekly consumption contributed towards the increase in the number of adolescents with carious lesions.

Obesity, and the diseases resulting therefrom, and dental caries, have, in dietary habit, an important common etiological component. The change in dietary habits, where foods that are rich in fiber and nutrients are replaced with processed foods, rich in fats and carbohydrates, helps the disease to take a hold, even when individuals are exposed to widely publicized protection factors, such as fluorides ${ }^{40}$. It can be seen from this study that both populations, rural and urban, have over $20 \%$ of adolescents who are overweight or obese, and both populations had a high consumption of processed foods and a large number of individuals with experience of caries.

Some studies show that the greater isolation of groups residing in rural areas (the distance from the town centers) results in lower access to sugary processed foods, an important factor in the recording of lower caries prevalence in these rural populations ${ }^{38}$. However, this study did not reveal differences in the consumption of processed foods and caries experience between the rural and urban areas, which leads us to conclude that the municipality's rural populations have free access to the urban centers and find themselves in the same process of dietary transition (from healthy products to processed foods).

The limitations of this study involve aspects inherent to cross-sectional studies, which do not permit us to infer causality. We should also stress that the population of schoolchildren in private schools was very small in comparison with those in public schools, however, the calculation of sample size and the manner in which the schools were selected do represent the regions of the municipality, assuring good internal and external validity. Our results are relevant as they underscore that programs focusing on oral health are still failing and need to be reviewed, as the caries picture is not changing, mainly when we ascertain that the age groupings are the same and the prevalence of caries is still extremely high - approximately seven out of every 10 adolescents has experienced caries.

Our findings should be interpreted with caution as our study is cross-sectional and it was not possible to ascertain if there was an increase or decrease in the prevalence of caries in the city due to the absence of prior surveys evaluating the intended population. The data found in the SB Brasil 2003 and 2010 projects reveal a reduction of $25 \%$ in the DMFT index for 12 year-olds in the period of the study ${ }^{4,32}$. Despite the projects following the same design and methodology, they show a discrepancy with regard to the overall objective, since in 2010 only the urban population was evaluated, which may have contributed to the difference in the index. Accordingly, our findings have higher indices than the national survey as they include participants from both zones.

As a final consideration, our results demonstrate that special attention should be paid towards the city's rural zone and its public schools. Access to health services and fluoridated water in the rural region should be investigated on a regular basis; programs and projects developed by the departments of health and education should be integrated and consistent with the needs of the target public. Our results also showed that diet is a primary factor for dental caries, nevertheless, we would emphasize that other aspects are fundamental to its understanding and prevention. Our country possesses many social facets, problems emanating from basic sanitation, education, safety and health, which should be treated under a global umbrella, it being understood that all these factors have an influence on the health and quality of life of our population. 


\section{CONCLUSION}

This study showed that dental caries continues to be a public health issue, as it affects a large proportion of the adolescent population in the municipality evaluated. Furthermore, socioeconomic factors, diet and hygiene habits continue to be heavily associated with the occurrence of dental caries. Despite our findings not bringing new information to the discussion, we can use all the information obtained from this survey to show that programs focusing on oral health need to be restructured since the caries picture is still only changing slowly. Therefore, it should be understood that, while the multifactorial nature and stratified action of caries disease is not taken into consideration, so that policies compatible with the susceptibility of each population can be planned, this situation will not change and the actions implemented

\section{REFERENCES}

1. Narvai PC. Avanços e desafios da Política Nacional de Saúde Bucal no Brasil. Tempus Actas Saúde Col. 2011;5(3):21-34.

2. WHO - World Health Organization. The World Oral Health Report 2003. Continuous improvement of oral health in the 21st century: the approach of the WHO Global Oral Health Programme. Geneva: WHO; 2003.

3. Brasil. Ministério da Saúde. Secretaria de Atenção à Saúde. Departamento de Atenção Básica. Coordenação Nacional de Saúde Bucal. Diretrizes da política nacional de saúde bucal [citado 2016 Fev 4]. Disponível em: <http://189.28.128.100/ dab/docs/publicacoes/geral/diretrizes_da_politica_nacional_de_ saude_bucal.pdf>.

4. Brasil. Ministério da Saúde. Secretaria de Atenção à Saúde. Secretaria de Vigilância em Saúde. SB Brasil 2010: Pesquisa Nacional de Saúde Bucal: resultados principais. Brasília: Ministério da Saúde; 2012 [citado 2016 Fev 4]. Disponível em: <http://dab.saude.gov.br/CNSB/sbbrasil/arquivos/projeto_ sb2010_relatorio_final.pdf>.

5. Levine RS, Nugent ZJ, Rudolf MC, Sahota P. Dietary patterns, toothbrushing habits and caries experience of schoolchildren in West Yorkshire, England. Community Dent Health. 2007 Jun;24(2):82-7.

6. Foschini ALR, Campos JADB. Associação da cárie dentária com indicadores antropométricos do estado nutricional em préescolares. Alim Nutr Araraquar. 2012;23(4):597-602.

7. John JB, Asokan S, Aswanth KP, Priya PR, Shanmugaavel AK. Dental caries and the associated factors influencing it in tribal, suburban and urban school children of Tamil Nadu, India: a cross sectional study. J Public Health Res. 2015 Mar 9;4(1):361. doi: 10.4081/jphr.2015.361

8. Damle SG, Patil A, Jain S, Damle D, Chopal N. Effectiveness of supervised toothbrushing and oral health education in improving oral hygiene status and practices of urban and rural will continue to fail, frustrating the expectations set by government entities.

\section{Collaborators}

TS BORGES, CP REUTER, MS BURGOS participated of the literature review, preparation of the methodology, collection, analysis and interpretation of the results, writing and approval of the manuscript's final version. SIRF participated of the literature review and data collection. MZC, MJF and SI participated in the analysis and interpretation of the results, writing and approval of the manuscript's final version. TS BORGES, MZ CARDOSO, MJ FORTUNA, CP REUTER S IMPERATORE, SIR FRANKE and MS BURGOS participated in the writing and approval of the manuscript's final version.

school children: A comparative study. J Int Soc Prev Community Dent. 2014 Sep;4(3):175-81. doi: 10.4103/2231-0762.142021

9. Mello TRC, Antunes JLF, Waldman EA. Prevalência de cárie não tratada na dentição decídua nas áreas urbanas e rurais do Estado de São Paulo, Brasil. Rev Panam Salud Publica. 2008;23(2):7884.

10. Junho KLS. Levantamento epidemiológico da cárie dentária de escolares de 5 a 12 anos, residentes na zona rural e urbana do município de Natércia, Minas Gerais, Brasil [monografia]. Belo Horizonte: Universidade Federal de Minas Gerais; 2010.

11. Mello TRC, Antunes JLF. Prevalence of dental caries in schoolchildren in the rural area of Itapetininga, São Paulo State, Brazil. Cad Saúde Pública. 2004;20(3):829-35. doi: 10.1590/ S0102-311X2004000300020

12. Dini EL, Silva SRC. Prevalence of caries and dental care status of schoolchildren from urban and rural areas in Araraquara, SP, Brazil. Int Dental J. 1994;14:613-6.

13. Sathananthan $K$, Vos T, Bango G. Dental caries, fluoride levels and oral hygiene practices of school children in Matebeleland South, Zimbabwe. Community Dent Oral Epidemiol. 1996;24(1):21-4. doi: 10.1111/j.1600-0528.1996.tb00806.x

14. Attin T, Mbiydzemo FN, Villard I, Kielbassa AM, Kielbassa AM, Hellwig E. Dental status of schoolchildren from a rural community in Cameroon. SADJ. 1999 Apr;54(4):145-8.

15. Brindle R, Wilkinson D, Harrison A, Connolly C, Cleaton-Jones P. Oral health in Hlabisa, KwaZulul/Natal - a rural school and community based survey. Int Dent J. 2000 Feb;50(1):13-20. doi: 10.1111/j.1875-595X.2000.tb00541.x

16. Instituto Brasileiro de Geografia e Estatística- IBGE [página da internet]. Diretoria de Pesquisas - DPE-Coordenação de População e Indicadores sociais- COPIS [citado 2016 Fev 4]. Disponível em: <http://www.cidades.ibge.gov.br/xtras/perfil.ph p?lang $=\&$ codmun $=431680 \&$ search=rio-grande do-sul|santacruz-do-sul> 
17. Rio Grande do Sul (Estado). Município de Santa Cruz do Sul [página da internet]. Secretaria de Educação e Cultura [citado 2016 Fev 4]. Disponível em: <http://www.santacruz.rs.gov.br/ secretarias/educacao-e-cultura>.

18. Organização Mundial da Saúde. Levantamento epidemiológico básico de saúde bucal: manual de instruções. $3^{\text {rd }}$ ed. São Paulo: Santos; 1991.

19. Associação Brasileira de Empresas de Pesquisa - ABEP-. Critério de Classificação Econômica no Brasil. Brasil: ABEP; 2009.

20. Conde WL, Monteiro CA. Body mass index cutoff points for evaluation of nutritional status in Brazilian children and adolescents. J Pediatr. 2006;82:266-72. doi: 10.2223/JPED.1502

21. Salas MMS, Dantas RVF, Sarmento HR, Vargas-Ferreira $F$, Torriani D, Demarco FF. Tooth erosion and dental caries in schoolchildren: is there a relationship between them? Braz J Oral Sci. 2014;13(1):12-6. doi: 10.1590/1677-3225v13n1a03

22. Aguiar YPC, dos Santos FG, Moura EFF, da Costa FCM, Auad SM, de Paiva SM, et al. Association between dental erosion and diet in brazilian adolescents aged from 15 to 19: a populationbased study. Sci World J. 2014;(2014):8181672014. doi: $10.1155 / 2014 / 818167$

23. Barros MVG, Nahas MV. Medidas da atividade física: teoria e aplicação em diversos grupos populacionais. Londrina: Midiograf; 2003.

24. Gushi LL, Soares MC, Forni TIB, Vieira V, Wada RS, de Sousa MLR. Dental caries in 15-to-19-year-old adolescents in São Paulo State, Brazil, 2002. Cad Saúde Pública. 2005;21(5):1383-91. doi: 10.1590/S0102-311X2005000500010

25. Hoffmann RHS, Cypriano S, de Sousa MLR, Wada RS. Dental caries experience in children at public and private schools from a city with fluoridated water. Cad. Saúde Pública. 2004;20(2):5228. doi: 10.1590/S0102-311X2004000200020

26. Zardetto CGDC. Prevalência de cárie dentária em adolescentes residentes no município de São Paulo: indicadores de risco e gravidade [tese]. São Paulo: Universidade de São Paulo; 2004.

27. Rihs LB. Inequalities in distribution of dental caries in teenagers of Indaiatuba, São Paulo State, 2004. Ciênc Saúde Coletiva. 2010;15(4):2173-80. doi: 10.1590/S141381232010000400031

28. Rodakowska E, Wilczynska-Borawska M, Baginska J, Stokowska E. Epidemiological analysis of dental caries in 12-year-old children residing in urban and rural settings in the Podlaskie region of north-eastern Poland. Ann Agric Environ Med. 2013;20(2):3258.

29. Gaszy凶ska E, Wierzbicka M, Marczak M, Szatko F. Thirty years of evolution of oral health behaviours and dental caries in urban and rural areas in Poland. Ann Agric Environ Med. 2014;21(3):557-61. doi: 10.5604/12321966.1120601.

30. Brasil. Ministério da Saúde. Divisão Nacional de Saúde Bucal. Levantamento epidemiológico em saúde bucal: Brasil, zona urbana. Brasil: Ministério da Saúde; 1986.
31. Brasil. Divisão Nacional de Saúde Bucal, Ministério da Saúde. Levantamento epidemiológico em saúde bucal 1996 - cárie dental [citado 2015 Out 10]. Disponível em: <http://tabnet. datasus.gov.br/cgi/sbucal/sbdescr.htm>.

32. Brasil. Ministério da Saúde. Secretaria de Atenção à Saúde. Departamento de Atenção Básica. Projeto SB Brasil 2003: condições de saúde bucal da população brasileira 2002-2003: resultados principais [citado 2016 Fev 4]. Disponível em: < http:// bvsms.saude.gov.br/bvs/publicacoes/condicoes_saude_bucal. pdf>.

33. Brasil. Ministério da Saúde. Coordenação Nacional de Saúde Bucal. Projeto SB Brasil 2010: manual da equipe de campo. Brasília: Ministério da Saúde; 2009 [citado 2016 Fev 4]. Disponível em: <http://dab.saude.gov.br/CNSB/sbbrasil/arquivos/ SBBrasil2010_Manual_Equipe_Campo.pdf>.

34. Moreira PVL. Prevalence of cavities among adolescents in public and private schools in João Pessoa, Paraíba State, Brazil. Ciênc Saúde Coletiva. 2007;12 (5):1229-36. doi: 10.1590/S141381232007000500020

35. Gomes DQC. Alterações estomatológicas em crianças de creches municipais da cidade de João Pessoa - PB. HU Rev. 2014;40(1):27-35

36. Ferreira SH, Béria JU, Kramer PF, Feldens EG, Feldens CA. Dental caries in 0- to 5-year-old Brazilian children: prevalence, severity, and associated factors. Int J Paediatr Dent. 2007 Jul;17(4):28996. doi: 10.1111/j.1365-263X.2007.00831.x

37. Kramer PF, Chaffee BW, Bertelli AE, Ferreira SH, Béria JU, Feldens CA. Gains in children's dental health differ by socioeconomic position: evidence of widening inequalities in southern Brazil. Int J Paediatr Dent. 2015;25(6):383-92. doi: 10.1111/ipd.12140

38. Menezes VA. Dental Caries and Feed Habits at Scholar Child of Rural Zone from Caruaru-PE. Odonto. 2010;18(36):83-94.

39. Noro LRA, Roncalli AG, Mendes Júnior FIR, Lima KC. Dental caries incidence in adolescents in a city Northeast Brazil, 2006. Cad Saúde Pública. 2009;25(4):783-90. doi: 10.1590/S0102$311 \times 2009000400009$

40. Traebert J, Moreira EAM, Bosco VL, Almeida ICS. Changing from breastfeeding to family feeding: a common problem for both obesity and dental caries. Rev Nutr. 2004;17(2):247-53. doi: $10.1590 /$ S1415-52732004000200011 